\title{
New Chalcone Derivative Inhibits ABCB1 in Multidrug Resistant T-cell Lymphoma and Colon Adenocarcinoma Cells
}

\author{
MARTINA ČIŽMÁRIKOVÁ ${ }^{1}$, PETER TAKÁČ ${ }^{2}$, GABRIELLA SPENGLER ${ }^{3}$, \\ ANNAMÁRIA KINCSES ${ }^{3}$, MÁRTA NOVÉ ${ }^{3}$, MÁRIA VILKOVÁ ${ }^{4}$ and JÁN MOJŽIŠ ${ }^{1}$ \\ ${ }^{1}$ Department of Pharmacology, Faculty of Medicine, University of Pavol Jozef Safarik, Kosice, Slovak Republic; \\ ${ }^{2}$ Institute of Human and Clinical Pharmacology, \\ University of Veterinary Medicine and Pharmacy in Kosice, Kosice, Slovak Republic; \\ ${ }^{3}$ Department of Medical Microbiology and Immunobiology, \\ Faculty of Medicine, University of Szeged, Szeged, Hungary; \\ ${ }^{4}$ Department of Organic Chemistry, Faculty of Science, \\ University of Pavol Jozef Safarik, Kosice, Slovak Republic
}

\begin{abstract}
Background/Aim: Development of new potential drugs to overcome multidrug resistance to chemotherapy is a big challenge for cancer treatment. Attention is also given to the natural compounds and their derivatives. The study aimed at evaluating the impact of a new chalcone derivative (IC) on multidrug resistant cell lines, focusing on P-glycoprotein $(P-g p, A B C B 1)$ inhibition, as well as $1 C$-doxorubicin interaction in vitro. Materials and Methods: Cytotoxic and antiproliferative effects of the $1 C$ compound were assessed by thiazolyl blue tetrazolium bromide (MTT) method in mouse T-cell lymphoma and human colon adenocarcinoma cells expressing $A B C B 1$. Alterations in $A B C B 1$ activity were evaluated by rhodamine 123 accumulation assay using flow cytometry. Drug-drug interaction was studied using combination assay. Results: Our results confirmed antiproliferative, cytotoxic, as well as $A B C B 1$ inhibitory potential of $1 C$ in both tested $A B C B 1$-expressing cancer cell lines. Furthermore, $1 C$ displayed synergistic interaction with doxorubicin. Conclusion: Our results suggest the $1 C$ chalcone derivative as a promising compound against
\end{abstract}

This article is freely accessible online.

Correspondence to: Martina Cizmarikova, Department of Pharmacology, Faculty of Medicine, University of Pavol Jozef Safarik, Trieda SNP 1, 04011 Kosice, Slovak Republic. Tel: +421 908343323, e-mail: martina.cizmarikova@upjs.sk; Peter Takac, Institute of Human and Clinical Pharmacology, University of Veterinary Medicine and Pharmacy in Kosice, Komenskeho 73, 041 81, Kosice, Slovak Republic. Tel: +421 902404493, e-mail: takacp3@gmail.com

Key Words: Chalcone, P-glycoprotein, ABCB1, doxorubicin, T-lymphoma, colon adenocarcinoma. resistant lymphoma and colon cancer, which could be used in monotherapy or in combination with other chemotherapeutics.

Several studies in many cancers have shown an association between overexpression of P-glycoprotein (P-gp, MDR1, lately named as $\mathrm{ABCB} 1$ ) and resistance to a number of structurally and functionally unrelated chemotherapeutics (multidrug resistance) $(1,2)$. This membrane protein can expel drugs from the cancer cells, preventing their pharmacological action (3). Currently, many cytostatics are considered as $\mathrm{ABCB} 1$ substrates (e.g. anthracyclines, antimetabolites) (4).

Until now, several ABCB1 inhibitors (e.g. verapamil, tariquidar) have been discovered to increase the sensitivity of multidrug-resistant cancer cells. However, due to their poor potency, high risk of side effects, and adverse interactions with concomitant chemotherapy, no ABCB1 inhibitor has been suitable for use in the clinic. Therefore, many researchers have focused their attention on searching for new molecules to overcome multidrug resistance (5-7). Within the last years, interest intensified in the group of natural phytochemicals and their derivatives as the fourth generation of multidrug resistance reversal agents $(4,8)$. Chalcones (1,3-diarylprop-2-en-1-ones) are precursors in the biosynthesis of flavonoids with a wide spectrum of biological activities (e.g. anti-inflammatory, antimicrobial, anticancer) $(9,10)$ and they represent one of the promising substances. Although their multidrug resistance reversal effect and potential to modulate ABCB1 activity have been evaluated in several cancer cell lines (11-18), their impact on colon cancer has not been studied yet.

In our recent study, we showed a strong antiproliferative activity of the new synthetic acridine chalcone derivative $1 \mathrm{C}$ on human colon adenocarcinoma cells and T-cell lymphoma 
(19). Therefore, the present work was focused on the investigation of antiproliferative, cytotoxic, and ABCB1 inhibitory effects of this compound in human colon adenocarcinoma cells and T-cell lymphoma cell lines overexpressing ABCB1. Additionally, the type of in vitro drug-drug interaction between compound $1 \mathrm{C}$ and doxorubicin was assessed.

\section{Materials and Methods}

Tested compound. (2E)-3-(acridin-9-yl)-1-(2,6-dimethoxyphenyl)prop2-en-1-one (1C) was synthetized at the Faculty of Natural Sciences of the P. J. Safarik University in Kosice.

Cell lines. The ABCB1-expressing T-cell lymphoma cell line (MDR) was obtained from parental L5178Y mouse T lymphoma cells (PAR) (ECACC Cat. No. 87111908, FDA, Silver Spring, MD, USA) after transfection with $\mathrm{pHaMDR} 1 / \mathrm{A}$ retrovirus and culturing of both cell lines, as previously described (7). The Colo 205, doxorubicin-sensitive (CCL-222) and Colo 320/MDR1-LRP multidrug resistant, overexpressing ABCB1-LRP (CCL-220.1) human colon adenocarcinoma cell lines were purchased from LGC Promochem (Teddington, UK). The cells were cultured in RPMI1640 medium (Sigma-Aldrich, St Louis, MO, USA) supplemented with $10 \%$ heat-inactivated foetal bovine serum (FBS; SigmaAldrich), $2 \mathrm{mM}$ L-glutamine (Sigma-Aldrich), $1 \mathrm{mM}$ Na-pyruvate, $100 \mathrm{mM}$ HEPES (Sigma-Aldrich), nystatin and a penicillinstreptomycin mixture (Sigma-Aldrich) at concentrations of $100 \mathrm{U} / 1$ and $10 \mathrm{mg} / 1$, respectively. The NIH/3T3 mouse embryonic fibroblast cell line (ATCC CRL-1658) (LGC Promochem, Teddington, UK) was cultured in Dulbecco's Modified Eagle's Medium (DMEM; Sigma-Aldrich), containing $4.5 \mathrm{~g} / \mathrm{l}$ glucose, supplemented with $10 \%$ heat-inactivated FBS, $2 \mathrm{mM}$ L-glutamine (Sigma-Aldrich), $1 \mathrm{mM}$ Na-pyruvate (Sigma-Aldrich), nystatin (Sigma-Aldrich) and a penicillin-streptomycin mixture (Sigma-Aldrich) in concentrations of $100 \mathrm{U} / 1$ and $10 \mathrm{mg} / \mathrm{l}$, respectively. The MRC-5 human embryonic lung fibroblast cell line (ATCC CCL-171) (LGC Promochem, Teddington, UK) was cultured in Eagle's Minimal Essential Medium (EMEM, Sigma-Aldrich), containing $4.5 \mathrm{~g} / \mathrm{l}$ glucose, supplemented with a non-essential amino acid (NEAA) mixture (Sigma-Aldrich), a selection of vitamins and $10 \%$ heat-inactivated FBS, 2 mM L-glutamine (Sigma-Aldrich), $1 \mathrm{mM}$ Na-pyruvate (Sigma-Aldrich), nystatin (Sigma-Aldrich) and a penicillinstreptomycin mixture (Sigma-Aldrich) at concentrations of $100 \mathrm{U} / 1$ and $10 \mathrm{mg} / \mathrm{l}$, respectively.

Cytotoxic and antiproliferative assay. The effects of decreasing concentrations of the synthetic chalcone derivative $1 \mathrm{C}$ on cell growth were determined by a 3-(4,5-dimethylthiazol-2-yl)-2,5-diphenyltetrazolium bromide (MTT) assay in 96-well cell culture microplates. The maximum concentration of tested compound was $20 \mu \mathrm{M}$. Cells (PAR, MDR, Colo 205 and Colo 320) were seeded at a density of $1 \times 10^{4}$ cells/well or $6 \times 10^{3}$ cells/well for cytotoxic and antiproliferative assay, respectively. After a 24-h (cytotoxic assay) or 72-h (antiproliferative assay) incubation at $37^{\circ} \mathrm{C}, 20 \mu \mathrm{l}$ of MTT (SigmaAldrich Chemie $\mathrm{GmbH}$, Steinheim, Germany) solution $(5 \mathrm{mg} / \mathrm{ml})$ were added to each well. After an additional incubation at $37^{\circ} \mathrm{C}$ for $4 \mathrm{~h}, 100 \mu \mathrm{l}$ of $10 \%$ sodium dodecyl sulphate (SDS, Sigma-Aldrich Chemie $\mathrm{GmbH}$ ) were added to each well to dissolve the produced formazan, and after $12 \mathrm{~h}$ optical density (OD) was measured. Additionally to $1 \mathrm{C}$, the effects of decreasing concentrations of doxorubicin (TEVA Pharmaceuticals, Debrecen, Hungary; maximum concentration $10 \mu \mathrm{M}$ ), verapamil (Sigma; maximum concentration $100 \mu \mathrm{M})$, which is known as $\mathrm{ABCB} 1$ substrate and inhibitor $(20,21)$, and DMSO (Sigma-Aldrich Chemie $\mathrm{GmbH}$; maximum concentration $1 \% \mathrm{v} / \mathrm{v}$ ) on cell growth were evaluated. Cytotoxic assay was also performed for the two non-cancerous cell lines NIH/3T3 and MRC$5\left(2 \times 10^{4}\right.$ cells/well). Overall, the cell growth was then determined by measuring the OD at $550 \mathrm{~nm}$ (ref. $630 \mathrm{~nm}$ ) with a Multiscan EX ELISA reader (Thermo Labsystems, Cheshire, WA, USA). Results obtained from MTT assay were used to determine the percentage of inhibition of cell growth. Absorbance of control wells (untreated cells) was taken as $100 \%$, and the inhibition of cell growth was expressed as a percent of control.

Flow cytometric analysis. The fluorescence-based rhodamine 123 accumulation assay was performed as previously described (7) in order to investigate the activity of $1 \mathrm{C}$ as $\mathrm{ABCB} 1$ modulator on both parental cancer cell lines (PAR, Colo 205) and the corresponding ABCB1-overexpressing sublines (MDR, Colo 320). Cells were adjusted to $2 \times 10^{6}$ cells $/ \mathrm{ml}$ and tested compound was added $(10 \mu \mathrm{l})$. Different concentrations $(0.5,1,2.5$ and $10 \mu \mathrm{M})$ of $1 \mathrm{C}$ as well as doxorubicin $(5 \mu \mathrm{M})$ were tested. Verapamil (Sigma; $20 \mu \mathrm{M})$ used in both cancer cell lines (MDR, Colo 320) served as reference inhibitor (positive control). DMSO at $1 \% \mathrm{v} / \mathrm{v}$ was used as solvent control. Rhodamine 123 fluorescent dye (Sigma) was added to the samples at a final concentration of $5.2 \mu \mathrm{M}$. The fluorescence of the cell population was measured with a Partec CyFlow ${ }^{\circledR}$ flow cytometer (Partec, Münster, Germany). The mean fluorescence and SD values were calculated from three independent experiments.

Drug combination assay. Serial dilutions of doxorubicin ranging from $17.24 \mu \mathrm{M}$ to $0.14 \mu \mathrm{M}$ were made in a horizontal direction $(100 \mu \mathrm{l})$, while serial dilutions of the drug resistance modifier were made vertically $(50 \mu \mathrm{l})$, in a microtiter plate. The MDR and Colo 320 cells were re-suspended in culture medium $\left(6 \times 10^{3}\right.$ cells/well) and seeded at a density $50 \mu \mathrm{l} /$ well. The plates were incubated for $72 \mathrm{~h}$ at $37^{\circ} \mathrm{C}$ in a $5 \% \mathrm{CO}_{2}$ incubator, and cell growth was determined by the MTT assay.

Statistical analysis. Results obtained from three independent MTT measurements were used to determine a half maximal inhibitory concentration $\left(\mathrm{IC}_{50}\right)$ and the mean $\pm \mathrm{SD}$ for each cell line. The results from rhodamine 123 assay were obtained from three independent flow cytometry experiments, in which at least 20,000 individual cells/measurement of the overall population were evaluated for rhodamine 123 retention. The percentage of mean fluorescence intensity was calculated for the treated MDR and Colo 320 cells as compared with the untreated cells. Rhodamine 123 accumulation was expressed as a fluorescence activity ratio (FAR) that was calculated based on the equation mentioned previously (7). Drug interactions were evaluated using CompuSyn software (www.combosyn.com, ComboSyn, Inc., Paramus, NJ, USA). Combination index $(\mathrm{CI})$ values at $50 \%$ of the growth inhibition dose $\left(\mathrm{ED}_{50}\right)$ with corresponding $\mathrm{SD}$ values were determined using the software to plot four to five data points to each ratio. CI values were calculated by means of the median-effect equation, where $\mathrm{CI}<1$, $\mathrm{CI}=1$, and $\mathrm{CI}>1$ represent synergism, additive effect (or no interaction), and antagonism, respectively (22). Student's t-test 
Table I. Cytotoxic effect of tested compounds on different cell lines $\left[I C_{50}(\mu M) \pm S D\right]$.

\begin{tabular}{lcccc}
\hline Compound & \multicolumn{4}{c}{ Cell lines } \\
\cline { 2 - 5 } & PAR & MDR & Colo 205 & Colo 320 \\
\hline $1 C$ & $4.64 \pm 0.24$ & $5.02 \pm 0.38$ & $9.20 \pm 1.37$ & $10.97 \pm 1.86$ \\
Verapamil & $15.81 \pm 1.18$ & $23.41 \pm 0.31^{* * *}$ & $43.21 \pm 2.28$ & $>100^{* * *}$ \\
Doxorubicin & $0.49 \pm 0.04$ & $11.15 \pm 0.56^{* * *}$ & $1.56 \pm 0.03$ & $6.45 \pm 0.19^{* * *}$ \\
\hline
\end{tabular}

PAR, Parental L5178Y mouse T-cell lymphoma cells; MDR, ABCB1transfected L5178Y cells. The results are presented from three independent experiments. ${ }^{* *} p<0.001$ (MDR vs. PAR, Colo $320 v s$. Colo 205).

Table II. Antiproliferative effect of tested compounds on different cell lines $\left[I C_{50}(\mu M) \pm S D\right]$.

\begin{tabular}{|c|c|c|c|c|}
\hline \multirow[t]{2}{*}{ Compound } & \multicolumn{4}{|c|}{ Cell lines } \\
\hline & PAR & MDR & Colo 205 & Colo 320 \\
\hline $1 \mathrm{C}$ & $3.47 \pm 0.40$ & $4.78 \pm 0.71$ & $3.84 \pm 0.25$ & $4.49 \pm 0.42$ \\
\hline Verapamil & $24.13 \pm 1.41$ & $25.82 \pm 0.28$ & $>100$ & $>100$ \\
\hline Doxorubicin & $0.03 \pm 0.01$ & $0.39 \pm 0.04 * * *$ & $0.24 \pm 0.03$ & $0.14 \pm 0.03^{*}$ \\
\hline
\end{tabular}

PAR, Parental L5178Y mouse T-cell lymphoma cells; MDR, ABCB1transfected L5178Y cells. The results are presented from three independent experiments. ${ }^{*} p<0.05,{ }^{* * *} p<0.001$ (MDR $v s$. PAR, Colo 320 vs. Colo 205).

(GraphPad Software, La Jolla, CA, USA) was employed to determine statistical significance. Differences were considered significant when $p$-values were lower than 0.05 .

\section{Results}

Effect of synthetic chalcone derivative $1 C$ on cell growth. The effect of the synthetic chalcone derivative $1 \mathrm{C}$ on cell growth was determined on mouse T-cell lymphoma cells and human colon adenocarcinoma cells expressing ABCB1 (MDR and Colo 320) or not (PAR and Colo 205) by MTT analysis. Overall, compared to the parental cell lines, $1 \mathrm{C}$ exerted weaker cytotoxic effects on multidrug resistant cell lines; nevertheless, 1C compound was still effective on these sub-lines (PAR vs. MDR: $\mathrm{IC}_{50} 4.64 \mu \mathrm{M}$ vs. $5.02 \mu \mathrm{M}, p \geq 0.05$; Colo $205 v s$. Colo 320: $\mathrm{IC}_{50} 9.20 \mu \mathrm{M}$ vs. $\left.10.97 \mu \mathrm{M}, p \geq 0.05\right)$. Similarly, antiproliferative activity was comparable (PAR vs. MDR: IC $_{50}$ $3.47 \mu \mathrm{M}$ vs. $4.78 \mu \mathrm{M}, p \geq 0.05$; Colo 205 vs. Colo 320: $\mathrm{IC}_{50} 3.84$ $\mu \mathrm{M}$ vs. $4.49 \mu \mathrm{M}, p \geq 0.05)$. On the other hand, in the cytotoxic assay, verapamil (ABCB1 substrate, inhibitor or inducer) and doxorubicin (ABCB1 substrate or inducer) (4) exhibited significantly decreased inhibition of cell growth in the resistant cell lines $(p<0.001)$. All $\mathrm{IC}_{50}$ values obtained from MTT assays (cytotoxic and antiproliferative) on cancer cell lines together
Table III. Cytotoxic effect of tested compounds on non-cancerous and cancer cell lines $\left[I C_{50}(\mu M) \pm S D\right]$.

\begin{tabular}{|c|c|c|c|}
\hline \multirow[t]{2}{*}{ Compound } & \multicolumn{3}{|c|}{ Cell lines } \\
\hline & NIH/3T3 & PAR & MDR \\
\hline $1 \mathrm{C}$ & $>20$ & $4.64 \pm 0.24 * * *$ & $5.02 \pm 0.38 * * *$ \\
\hline Verapamil & $>100$ & $15.81 \pm 1.18^{* * *}$ & $23.41 \pm 0.31 * * *$ \\
\hline \multirow[t]{2}{*}{ Doxorubicin } & $5.71 \pm 0.50$ & $0.49 \pm 0.04 * * *$ & $11.15 \pm 0.56^{* * *}$ \\
\hline & MRC-5 & Colo 205 & Colo 320 \\
\hline $1 \mathrm{C}$ & $>20$ & $9.20 \pm 1.37 * * *$ & $10.97 \pm 1.86^{* *}$ \\
\hline Verapamil & $>100$ & $43.21 \pm 2.28 * * *$ & $>100 * * *$ \\
\hline Doxorubicin & $>10$ & $1.56 \pm 0.03 * * *$ & $6.45 \pm 0.19 * * *$ \\
\hline
\end{tabular}

PAR, Parental L5178Y mouse T-cell lymphoma cells; MDR, $A B C B 1$ transfected L5178Y cells. The results are presented from three independent experiments. $* * p<0.01, * * * p<0.001$ (PAR/MDR $v s$. NIH/3T3, Colo 205/Colo 320 vs. MRC-5).

with $\mathrm{IC}_{50}$ of verapamil and doxorubicin are summarized in Table I and Table II, respectively. Moreover, it was demonstrated that $1 \mathrm{C}$ had significantly decreased inhibitory effects on non-cancerous cell lines (mouse NIH/3T3 and human MRC-5 cells) than on the tested cancer cell lines $(p<0.001$ or $p<0.01$; Table III). DMSO did not show any inhibitory activity on cell growth at a concentration of $1 \% \mathrm{v} / \mathrm{v}$ in all experiments.

To sum up, in addition to potent cytotoxic and antiproliferative effects on cell lines expressing ABCB1 or not, the tested compound $1 \mathrm{C}$ showed lower toxicity against non-cancer cells.

Effect of synthetic chalcone derivative $1 C$ on $A B C B 1$ transporter. Due to the potent cell growth inhibitory effect of $1 \mathrm{C}$ on cell lines expressing ABCB1, we next analysed whether compound $1 \mathrm{C}$ affects $\mathrm{ABCB} 1$ efflux activity in cancer cells. Thus, rhodamine 123 accumulation assay was performed using rhodamine 123 as an ABCB1-specific substrate. Briefly, parental cells (PAR, Colo 205) and their sub-lines expressing ABCB1 (MDR, Colo 320) were treated with $1 \mathrm{C}$, doxorubicin, as well as verapamil as positive control and DMSO as negative control. The accumulation of rhodamine 123 was evaluated by flow cytometry. The resulting values of mean fluorescence intensity of the cells (FL-1) \pm SD values and fluorescence activity ratio (FAR) are summarized in Table IV (for mouse T-lymphoma cells) and Table V (for human colon adenocarcinoma cells). The potential of compounds to modulate ABCB1 was estimated from FAR values, which were calculated using the formula presented previously (7). Our compound $1 \mathrm{C}$ at concentrations $\geq 1 \mu \mathrm{M}$ was able to significantly increase rhodamine 123 accumulation in MDR cell line, compared to untreated MDR 
Table IV. Rhodamine 123 accumulation in mouse T-lymphoma cells.

\begin{tabular}{lrrr}
\hline Samples & $\begin{array}{c}\text { Concentration } \\
(\mu \mathrm{M})\end{array}$ & FL-1 \pm SD & FAR \\
\hline Untreated PAR & - & $92.60 \pm 1.40$ & - \\
Untreated MDR & - & $0.52 \pm 0.02$ & 1 \\
Treated MDR & & & \\
Verapamil & 20 & $0.99 \pm 0.05$ & $1.90^{* * *}$ \\
Doxorubicin & 5 & $0.82 \pm 0.03$ & $1.58^{* * *}$ \\
$1 \mathrm{C}$ & 0.5 & $9.58 \pm 6.72$ & 18.42 \\
$1 \mathrm{C}$ & 1 & $23.10 \pm 5.12$ & $44.42^{* *++}$ \\
$1 \mathrm{C}$ & 2.5 & $66.60 \pm 1.57$ & $128.08^{* * *+++}$ \\
$1 \mathrm{C}$ & 10 & $92.20 \pm 4.72$ & $177.31^{* * *+++}$ \\
DMSO $(\% \mathrm{v} / \mathrm{v})$ & 1.0 & $0.44 \pm 0.13$ & 0.85 \\
\hline
\end{tabular}

FL-1, Mean fluorescence intensity of the cells; SEM, standard error of the mean; FAR, fluorescence activity ratio, PAR, parental L5178Y mouse T-cell lymphoma cells; MDR, ABCB1-transfected L5178Y cells. All data represent the means \pm SD of three independent experiments. ${ }^{* *} p<0.01,{ }^{* * *} p<0.001$ (treated MDR $v s$. untreated MDR); ${ }^{++} p<0.01$, ${ }^{+++} p<0.001$ (1C vs. verapamil).

Table V. Rhodamine 123 accumulation in human colon adenocarcinoma cells.

\begin{tabular}{lcrr}
\hline Samples & $\begin{array}{c}\text { Concentration } \\
(\mu \mathrm{M})\end{array}$ & FL-1 \pm SD & FAR \\
\hline Untreated Colo 205 & - & $96.20 \pm 5.05$ & - \\
Untreated Colo 320 & - & $1.95 \pm 0.47$ & 1 \\
Treated Colo 320 & & & \\
Verapamil & 20 & $13.50 \pm 3.40$ & $6.92^{* *}$ \\
Doxorubicin & 5 & $1.78 \pm 0.08$ & 0.91 \\
1C & 0.5 & $9.93 \pm 3.51$ & $5.90^{*}$ \\
1C & 1 & $18.60 \pm 3.12$ & $9.54^{* * *}$ \\
1C & 2.5 & $29.50 \pm 2.87$ & $15.13^{* * *++}$ \\
1C & 10 & $61.50 \pm 5.20$ & $31.54^{* * *+++}$ \\
DMSO $(\% \mathrm{v} / \mathrm{v})$ & 1.0 & $1.45 \pm 0.52$ & 0.74 \\
\hline
\end{tabular}

FL-1, Mean fluorescence intensity of the cells; SEM, standard error of the mean; FAR, fluorescence activity ratio. All data represent the means \pm SD of three independent experiments. ${ }^{*} p<0.05$, $* * p<0.01$, $* * * p<0.001$ (treated Colo 320 vs. untreated Colo 320 ); ${ }^{++} p<0.01$, ${ }^{+++} p<0.001$ (1C vs. verapamil).

cells $(1 \mu \mathrm{M}: p<0.01,2.5 \mu \mathrm{M}: p<0.001$, and $10 \mu \mathrm{M}: p<0.001)$ (Table IV). A similar effect of $1 \mathrm{C}$-induced increase in rhodamine 123 accumulation was observed in Colo 320 cells treated with $1 \mathrm{C}$, compared to the same untreated cell line $(0.5$ $\mu \mathrm{M}: p<0.05,1,2.5$, and $10 \mu \mathrm{M}: p<0.001$ ) (Table V). Moreover, accumulation of rhodamine 123 was significantly higher in $1 \mathrm{C}$-treated resistant cancer cell lines in comparison with the same cell lines treated with verapamil (MDR: $p<0.001$ at concentration of $1 \mathrm{C} \geq 2.5 \mu \mathrm{M}, \quad p<0.01$ at concentration of $1 \mathrm{C}=1 \quad \mu \mathrm{M}$; Colo320: $p<0.001$ at concentration of $1 \mathrm{C}=10 \mu \mathrm{M}, p<0.01$ at concentration of $1 \mathrm{C}=2.5 \mu \mathrm{M})($ Table IV and Table V).
Table VI. The type of interaction between the synthetic chalcone derivative $1 C$ and doxorubicin.

\begin{tabular}{lcccc}
\hline Cell lines & Best ratio $^{1}$ & CI $^{\text {at ED502 }}$ & SD & Interaction \\
\hline MDR & $4.64: 1$ & 0.62 & 0.09 & Synergism \\
Colo 320 & $4.64: 1$ & 0.50 & 0.07 & Synergism \\
\hline
\end{tabular}

${ }^{1}$ Data are shown as the best combination ratio between $1 \mathrm{C}$ and doxorubicin. ${ }^{2}$ Combination index $(\mathrm{CI})$ values at the $50 \%$ growth inhibition dose $\left(\mathrm{ED}_{50}\right)$ were determined by the CompuSyn software to plot four to five data points at each ratio. CI values were calculated by means of the median-effect equation, where $\mathrm{CI}<1$, represent synergism. MDR, ABCB1-transfected L5178Y mouse T-cell lymphoma cells; SD, standard deviation.

Overall, the tested chalcone $1 \mathrm{C}$ enhanced accumulation of known ABCB1 substrate (rhodamine 123) more strongly than verapamil.

Combination assay between synthetic chalcone derivative $1 C$ and doxorubicin. In order to find out the type of in vitro drug-drug interaction between the compound $1 \mathrm{C}$ and the cytostatic drug doxorubicin (known ABCB1 substrate) (23), a combination assay was carried out on the resistant MDR and Colo 320 cell lines. Several concentrations of the compound $1 \mathrm{C}$ and doxorubicin were assessed. The type of interaction between tested substances was calculated and expressed using the combination index $(\mathrm{CI})$ value \pm standard deviation. Tested chalcone derivative displayed synergistic interaction with doxorubicin, being able to enhance inhibition of cell growth of both drug-resistant cancer cell lines (MDR: $\mathrm{CI}$ at $\mathrm{ED}_{50}=0.62$, Colo 320: $\mathrm{CI}$ at $\mathrm{ED}_{50}=0.50$ ). The best combination ratios between $1 \mathrm{C}$ and doxorubicin were also determined (Table VI).

In conclusion, the tested chalcone increased cell growth inhibition of doxorubicin in both tested cell lines.

\section{Discussion}

To our knowledge, this is the first study that assessed ABCB1 reversal effect of chalcone derivative in human colon adenocarcinoma cells, in addition to the effect on mouse Tlymphoma cells that has been tested (14). The choice of tested cancer cell lines (PAR, MDR, Colo 205 and Colo 320) and selection of chalcone derivative was in accordance to our recent study, which demonstrated a strong antiproliferative activity of the chalcone derivative $1 \mathrm{C}$ in human colorectal HCT116 cells and human T-cell lymphoma (19).

In the present work, we found that compound $1 \mathrm{C}$ had potent antiproliferative and cytotoxic effects on parental cancer cell lines (PAR, Colo 205), as well as on their resistant sub-lines expressing $\mathrm{ABCB} 1$, with comparable $\mathrm{IC}_{50}$ 
values. Therefore, our findings suggest that expression of $\mathrm{ABCB} 1$ was not able to abolish the cytotoxic effect of $1 \mathrm{C}$. The important factor influencing the cytotoxicity of chalcones against multidrug resistant cancer cell lines is considered to be a presence of a methoxy substituent in the scaffold, whereas chalcones with two methoxy groups show better activity than chalcones with only one (24). The fact that chalcone $1 \mathrm{C}$ contains two methoxy groups may be critical for the mediation of its strong antiproliferative activity toward the tested cell lines. Previous studies have demonstrated inhibition of cell growth induced by methoxy chalcones in cells from various cancer types (e.g. synovial sarcoma, prostate cancer, colon cancer, bladder cancer, and human oral squamous cell carcinoma) $(25,26)$, as well as in multidrug resistant cells (mouse T-cell lymphoma-L5178, human leukemia-CEM/ADR5000 or colon cancer-LoVo/DX) (14, 24, 27).

Interestingly, toxicity of $1 \mathrm{C}$ against non-cancerous mouse $\mathrm{NIH} / 3 \mathrm{~T} 3$ and human MRC-5 cells was markedly reduced, which is a crucial parameter to ensure safety of anticancer treatment. Such a preferential action of chalcones against cancer cells and not non-cancer cells has also been documented in other studies $(26,28-30)$.

Furthermore, our analysis showed that $1 \mathrm{C}$ could inhibit ABCB1 mediated efflux of rhodamine 123 (ABCB 1 substrate). In line with our findings, there are several additional studies reporting the ability of chalcones to bind to $\mathrm{ABCB} 1$ and inhibit its transport activity $(12,31)$ Multidrug resistance reversal activity of chalcones, including inhibition of other membrane transporters, has been previously demonstrated for example in human breast cancer $(15,32,33)$ or human glioblastoma cells (13). Herein, the tested chalcone $1 \mathrm{C}$ was even more potent inhibitor of $\mathrm{ABCB} 1$ than verapamil. In literature, other chalcones have been shown to inhibit ABCB1 activity more potently than verapamil $(14,15)$. The precise mechanism by which chalcones inhibit ABCB1 is still not fully understood; however, according to several authors, chalcones can overlap two binding sites of the nucleotide-binding domain (NBD2) of $\mathrm{ABCB} 1(17,34)$. The key factors influencing ABCB1 inhibitory activity of chalcones are believed to be lipophilicity as well as the size and shape of molecules (17). Structure-activity relationship (SAR) studies have shown that the presence of methoxy groups $\left(-\mathrm{OCH}_{3}\right)$ on ring A or basic functional groups (i.e. nitrogen-containing heterocycles) on ring $\mathrm{B}$ of chalcone scaffold is favourable for an interaction with $\mathrm{ABCB} 1(12,13,16,35)$. The substitution of ring A by two methoxy groups and ring $\mathrm{B}$ by a basic acridine group in $1 \mathrm{C}$ molecule probably played an important role in facilitation of ABCB1 inhibition; however, further experiments are necessary to clarify the precise mechanism of its action.

Combination therapy in cancer treatment is an essential approach used to reduce drug resistance (36). Thus, in order to know the type of drug-drug interaction at the cellular level, in vitro combination chemotherapy model was performed. Compound $1 \mathrm{C}$ was combined with the anticancer drug doxorubicin, a well-known ABCB1 substrate and inducer. Herein, we observed that the tested chalcone derivative displayed synergistic interaction with doxorubicin leading to enhancement of cell growth inhibition in both cancer cell lines expressing ABCB1. Similarly, Arianingrum et al. observed synergistic effects of a synthetic chalcone with doxorubicin in breast cancer cells (37), while another synthetic chalcone was shown to sensitize epithelial cancer to cisplatin also displaying synergism (38). However, preclinical in vivo studies are needed to evaluate drug-drug interactions because of a greater impact of ABCB 1 on drug intestinal absorption and distribution.

To conclude, results presented here demonstrated dual potential of the chalcone $1 \mathrm{C}$ to act as a chemotherapeutic, as well as a chemosensitizing agent in resistant T-cell lymphoma and colon cancer, even with higher sensitivity for cancer cells. Furthermore, due to the ABCB1 inhibitory activity, the compound could be potentially used as an ABCB1 inhibitor in lab analyses.

\section{Conflicts of Interest}

The Authors declare that there are no conflicts of interest.

\section{Authors' Contributions}

M. Cizmarikova and P. Takac contributed to the study design, experimental work, article drafting, statistical analysis and data interpretation. G. Spengler contributed to the study design, experimental work, statistical analysis and data interpretation, provided critical revision of the article and obtained funding. A. Kincses and M. Nové contributed to the experimental work, statistical analysis and data interpretation. M. Vilkova synthesized the studied compound. J. Mojzis revised the paper, obtained funding and gave final approval.

\section{Acknowledgements}

This study was supported by the project GINOP- 2.3.2-15-201600012 (Hungary) and the Slovak Research and Development Agency under the contract No. APVV-16-0446.

\section{References}

1 Chen Z, Shi T, Zhang L, Zhu P, Deng M, Huang C, Hu T, Jiang $\mathrm{L}$ and Li J: Mammalian drug efflux transporters of the ATP binding cassette $(\mathrm{ABC})$ family in multidrug resistance: a review of the past decade. Cancer Lett 370: 153-164, 2016. PMID: 26499806. DOI: 10.1016/j.canlet.2015.10.010

2 He C, Sun Z, Hoffman RM, Yang Z, Jiang Y, Wang L and Hao $\mathrm{Y}$ : P-glycoprotein Overexpression is associated with cisplatin resistance in human osteosarcoma. Anticancer Res 39: 17111718, 2019. PMID: 30952710. DOI: 10.21873/anticanres.13277 
3 Robey RW, Pluchino KM, Hall MD, Fojo AT, Bates SE and Gottesman MM: Revisiting the role of $\mathrm{ABC}$ transporters in multidrug-resistant cancer. Nat Rev Cancer 18: 452-464, 2018. PMID: 29643473. DOI: 10.1038/s41568-018-0005-8

4 Genovese I, Ilari A, Assaraf YG, Fazi F and Colotti G: Not only P-glycoprotein: Amplification of the ABCB1-containing chromosome region $7 \mathrm{q} 21$ confers multidrug resistance upon cancer cells by coordinated overexpression of an assortment of resistance-related proteins. Drug Resist Updat 46: 23-46, 2017. PMID: 29145976. DOI: 10.1016/j.drup.2017.10.003

5 Satonaka H, Ishida K, Takai M, Koide R, Shigemasa R, Uevama J, Ishikawa T, Havashi K, Goto $\mathrm{H}$ and Wakusawa $\mathrm{S}$ : (-)Epigallocatechin-3-gallate Down-regulates doxorubicin-induced overexpression of P-glycoprotein through the coordinate inhibition of PI3K/Akt and MEK/ERK signaling pathways. Anticancer Res 37: 6071-6077, 2018. PMID: 29061787. DOI: 10.21873/anticanres.12055

6 Bourichi S, Misbahi H, Rodi YK, Chahdi FO, Essassi EM, Szabó S, Szalontai B, Gajdács M, Molnár J and Spengler G: In vitro evaluation of the multidrug resistance reversing activity of novel imidazo[4,5-b]pyridine derivatives. Anticancer Res 38: 3999-4003, 2018. PMID: 29970523. DOI: 10.21873/anticanres. 12687

7 Spengler G, Kincses A, Rácz B, Varga B, Watanabe G, Saijo R, Sekiya H, Tamai E, Maki J, Molnár J and Kawase M: Benzoxazole-based $\mathrm{Zn}(\mathrm{II})$ and $\mathrm{Cu}(\mathrm{II})$ complexes overcome multidrug-resistance in cancer. Anticancer Res 38: 6181-6187, 2018. PMID: 30396935. DOI: 10.21873/anticanres.12971

8 Kumar A and Jaitak V: Natural products as multidrug resistance modulators in cancer. Eur J Med Chem 176: 268-291, 2019. PMID: 31103904. DOI: 10.1016/j.ejmech.2019.05.027

9 Singh P, Anand A and Kumar V: Recent developments in biological activities of chalcones: A mini review. Eur J Med Chem 85: 758-777, 2014. PMID: 25137491. DOI: 10.1016/ j.ejmech.2014.08.033

10 Pilatova M, Varinska L, Perjesi P, Sarissky M, Mirossay L, Solar $\mathrm{P}$, Ostro $\mathrm{A}$ and Mojzis $\mathrm{J}$ : In vitro antiproliferative and antiangiogenic effects of synthetic chalcone analogues. Toxicol Vitro 24: 1347-1355, 2010. PMID: 20450969. DOI: 10.1016/ j.tiv.2010.04.013

11 Bois F, Beney C, Boumendjel A, Mariotte AM, Conseil G and Di Pietro A: Halogenated chalcones with high-affinity binding to P-glycoprotein: Potential modulators of multidrug resistance. J Med Chem 41: 4161-4164, 1998. PMID: 9767651. DOI: $10.1021 / \mathrm{jm} 9810194$

12 Liu XL, Tee HW and Go ML: Functionalized chalcones as selective inhibitors of P-glycoprotein and breast cancer resistance protein. Bioorg Med Chem 16: 171-180, 2008. PMID: 17964170. DOI: $10.1016 /$ j.bmc.2007.10.006

13 Boumendjel A, McLeer-Florin A, Champelovier P, Allegro D, Muhammad D, Souard F, Derouazi M, Peyrot V, Toussaint B and Boutonnat $\mathrm{J}$ : A novel chalcone derivative which acts as a microtubule depolymerising agent and an inhibitor of P-gp and $\mathrm{BCRP}$ in in vitro and in vivo glioblastoma models. BMC Cancer 9: 242, 2009. PMID: 19619277. DOI: 10.1186/14712407-9-242

14 Ivanova AB, Batovska DI, Todorova IT, Stamboliyska BA, Serly $\mathrm{J}$ and Molnar J: Comparative study on the MDR reversal effects of selected chalcones. Int J Med Chem 2011: 530780, 2011. PMID: 27516904. DOI: 10.1155/2011/530780
15 Gu X, Ren Z, Tang X, Peng H, Ma Y, Lai Y, Peng S and Zhang Y: Synthesis and biological evaluation of bifendate-chalcone hybrids as a new class of potential P-glycoprotein inhibitors. Bioorg Med Chem 20: 2540-2548, 2012. PMID: 22429509. DOI: $10.1016 /$ j.bmc.2012.02.050

16 Parveen Z, Brunhofer G, Jabeen I, Erker T, Chiba P and Ecker GF: Synthesis, biological evaluation and 3D-QSAR studies of new chalcone derivatives as inhibitors of human P-glycoprotein. Bioorg Med Chem 22: 2311-2399, 2014. PMID: 24613626. DOI: 10.1016/j.bmc.2014.02.005

17 Silbermann K, Shah CP, Sahu NU, Juvale K, Stefan SM, Kharkar PS and Wiese M: Novel chalcone and flavone derivatives as selective and dual inhibitors of the transport proteins ABCB1 and ABCG2. Eur J Med Chem 164: 193-213, 2019. PMID: 30594677. DOI: 10.1016/j.ejmech.2018.12.019

18 Yin H, Dong J, Cai Y, Shi X, Wang H, Liu G, Tang Y, Liu J and Ma L: Design, synthesis and biological evaluation of chalcones as reversers of P-glycoprotein-mediated multidrug resistance. Eur J Med Chem 180: 350-366, 2019. PMID: 31325783. DOI: 10.1016/j.ejmech.2019.05.053

19 Takac P, Kello M, Pilatova MB, Kudlickova Z, Vilkova M, Slepcikova P, Petik P and Mojzis J: New chalcone derivative exhibits antiproliferative potential by inducing $\mathrm{G}_{2} / \mathrm{M}$ cell cycle arrest, mitochondrial-mediated apoptosis and modulation of MAPK signalling pathway. Chem Biol Interact 292: 37-49, 2018. PMID: 29981726. DOI: 10.1016/j.cbi.2018.07.005

20 Sasongko L, Link JM, Muzi M, Mankoff DA, Yang X, Collier AC, Shoner SC and Unadkat JD: Imaging P-glycoprotein transport activity at the human blood-brain barrier with positron emission tomography. Clin Pharmacol Ther 77: 503-514, 2005. PMID: 15961982. DOI: 10.1016/j.clpt.2005.01.022

21 Cornwell MM, Pastan I and Gottesman MM: Certain calcium channel blockers bind specifically to multidrug-resistant human $\mathrm{KB}$ carcinoma membrane vesicles and inhibit drug binding to $\mathrm{P}-$ glycoprotein. J Biol Chem 262: 2166-2170. PMID: 2434476.

22 Chou TC: Theoretical basis, experimental design, and computerized simulation of synergism and antagonism in drug combination studies. Pharmacol Rev 58: 621-681, 2006. PMID: 16968952. DOI: $10.1124 /$ pr.58.3.10

23 Shen F, Chu S, Bence AK, Bailey B, Xue X, Erickson PA, Montrose MH, Beck WT and Erickson LC: Quantitation of doxorubicin uptake, efflux, and modulation of multidrug resistance (MDR) in MDR human cancer cells. J Pharmacol Exp Ther 324: 95-102, 2008. PMID: 17947497. DOI: 10.1124/ jpet.107.127704

24 Kuete V, Mbaveng AT, Zeino M, Fozing CD, Ngameni B, Kapche GD, Ngadjui BT and Efferth T: Cytotoxicity of three naturally occurring flavonoid derived compounds (artocarpesin, cycloartocarpesin and isobavachalcone) towards multi-factorial drug-resistant cancer cells. Phytomedicine 22: 1096-1102, 2015. PMID: 26547532. DOI: 10.1016/j.phymed .2015.07.006

25 Abu N, Ho WY, Yeap SK, Akhtar MN, Abdullah MP, Omar AR and Alitheen NB: The flavokawains: uprising medicinal chalcones. Cancer Cell Int 13: 102, 2013. PMID: 24148263. DOI: $10.1186 / 1475-2867-13-102$

26 Sakagami H, Masuda Y, Tomomura M, Yokose S, Uesawa Y, Ikezoe N, Asahara D, Takao K, Kanamoto T, Terakubo S, Kagaya H, Nakashima H and Sugita Y: Quantitative structurecytotoxicity relationship of chalcones. Anticancer Res 37: 10911098, 2017. PMID: 28314269. DOI: 10.21873/anticanres.11421 
27 Stompor M, Świtalska M, Podgórski R, Uram Ł4, Aebisher D and Wietrzyk J: Synthesis and biological evaluation of 4'-Oacetyl-isoxanthohumol and its analogues as antioxidant and antiproliferative agents. Acta Biochim Pol 64: 577-583, 2017. PMID: 28803257. DOI: 10.18388/abp.2017_1608

28 Zhang EH, Wang RF, Guo SZ and Liu B: An update on antitumor activity of naturally occurring chalcones. Evid Based Complement Alternat Med 2013: 815621, 2013. PMID: 23690855. DOI: $10.1155 / 2013 / 815621$

29 Xu S, Chen M, Chen W, Hui J, Ji J, Hu S, Zhou J, Wang Y and Liang G: Chemopreventive effect of chalcone derivative, L2H17, in colon cancer development. BMC Cancer 15: 870, 2015. PMID: 26552551. DOI: 10.1186/s12885-015-1901-x

30 Podolski-Renić A, Bősze S, Dinić J, Kocsis L, Hudecz F, Csámpai $\mathrm{A}$ and Pešić M: Ferrocene-cinchona hybrids with triazolyl-chalcone linkers act as pro-oxidants and sensitize human cancer cell lines to paclitaxel. Metallomics 9: 1132-1141, 2017. PMID: 28737782. DOI: $10.1039 / \mathrm{c} 7 \mathrm{mt} 00183 \mathrm{e}$

31 Riaz S, Iqbal M, Ullah R, Zahra R, Chotana GA, Faisal A and Saleem RSZ: Synthesis and evaluation of novel $\alpha$-substituted chalcones with potent anti-cancer activities and ability to overcome multidrug resistance. Bioorg Chem 87: 123-135, 2019. PMID: 30884306. DOI: 10.1016/j.bioorg.2019.03.014

32 Juvale K, Pape VF and Wiese M: Investigation of chalcones and benzochalcones as inhibitors of breast cancer resistance protein. Bioorg Med Chem 20: 346-355, 2012. PMID: 22112540. DOI: 10.1016/j.bmc.2011.10.074

33 Winter E, Gozzi GJ, Chiaradia-Delatorre LD, Daflon-Yunes N, Terreux R, Gauthier C, Mascarello A, Leal PC, Cadena SM, Yunes RA, Nunes RJ, Creczynski-Pasa TB and Di Pietro A: Quinoxaline-substituted chalcones as new inhibitors of breast cancer resistance protein ABCG2: polyspecificity at B-ring position. Drugs Des Devel Ther 8: 609-619, 2014. PMID: 24920885. DOI: $10.2147 /$ DDDT.S56625
34 Schmitt F, Draut H, Biersack B and Schobert R: Halogenated naphthochalcones and structurally related naphthopyrazolines with antitumor activity. Bioorg Med Chem Lett 26: 5168-5171, 2016. PMID: 27727127. DOI: 10.1016/j.bmcl.2016.09.076

35 Seelig A and Landwojtowicz E: Structure-activity relationship of P-glycoprotein substrates and modifiers. Eur J Pharm Sci 12: 31-40, 2000. PMID: 11121731. DOI: 10.1016/S0928-0987(00) 00177-9

36 Mokhtari RB, Homayouni TS, Baluch N, Morgatskaya E, Kumar $\mathrm{S}$, Das B and Yeger H: Combination therapy in combating cancer. Oncotarget 8: 38022-38043, 2017. PMID: 28410237. DOI: 10.18632 /oncotarget.16723

37 Arianingrum R, Sunarminingsih R, Meiyanto E and Mubarika $\mathrm{S}$ : Synergistic effects of para-hydroxy meta-methoxy chalcone (pHmMC)-doxorubicin treatments on T47D breast cancer cells. I J Biotech 20: 141-151, 2015. DOI: 10.22146/ijbiotech.24197

38 Su YK, Huang WC, Lee WH, Bamodu OA, Zucha MA, Astuti I, Suwito H, Yeh CT and Lin CM: Methoxyphenyl chalcone sensitizes aggressive epithelial cancer to cisplatin through apoptosis induction and cancer stem cell eradication. Tumour Biol 39: 1-12, 2017. PMID: 28466786. DOI: 10.1177/1010428 317691689
Received September 10, 2019

Revised October 31, 2019

Accepted November 8, 2019 